\title{
CAO NGUYÊN ĐÁ ĐỒNG VĂN - CÔNG VIÊN ĐỊA CHẤT TOÀN CẦU ĐẦU TIÊN CỦA VIÊT NAM VÀ VẤN ĐỀ BẢO TỒN DI SẢN ĐỊA CHÂT
}

\author{
LA THẾ PHÚC ${ }^{1}$, TRẦN TÂN VĂN ${ }^{2}$, LƯƠNG THI TUÂT ${ }^{2}$, \\ ĐOÀN THÊ $\mathrm{ANH}^{2}$, HỒ TIẾN CHUNG ${ }^{2}$, ĐẶNG TRẦ HUYÊN ${ }^{2}$, \\ NGUYỄN XUÂN KHIỄN ${ }^{2}$, ĐÀM NGỌC ${ }^{2}$, ĐỖ THI YẾN NGỌC ${ }^{2}$, \\ NGUYỄN ĐẠI TRUNG ${ }^{2}$, PHẠM KHẢ TƯY ${ }^{2}$, TRUƠNG QUANG QUÝ ${ }^{1}$ \\ E-mail: laphuc@gmail.com \\ ${ }^{1}$ Bảo tàng Địa chất \\ ${ }^{2}$ Viện Khoa học Địa chất và Khoáng sản
}

Ngày nhận bài: 14-12-2010

\section{Giới thiệu}

Cao nguyên đá Đồng Văn nằm ở cực Bắc nước ta, có diện tích $2.356 \mathrm{~km}^{2}$, bao gồm toàn bộ 4 huyện của tỉnh Hà Giang là: Đồng Văn, Mèo Vạc, Yên Minh và Quản $\mathrm{Bạ} \mathrm{(hình} \mathrm{1).}$
Nơi đây có khí hậu mát mẻ, núi non hùng vỹ vào bậc nhất của Việt Nam, điều kiện tự nhiên thuận lợi cho việc hình thành các di sản địa chất độc đáo và đa dạng, sinh vật phát triển phong phú, di sản văn hóa (DSVH) đa dạng đậm đà bản sắc dân tộc. Dưới đây là một số di sản tiêu biểu:

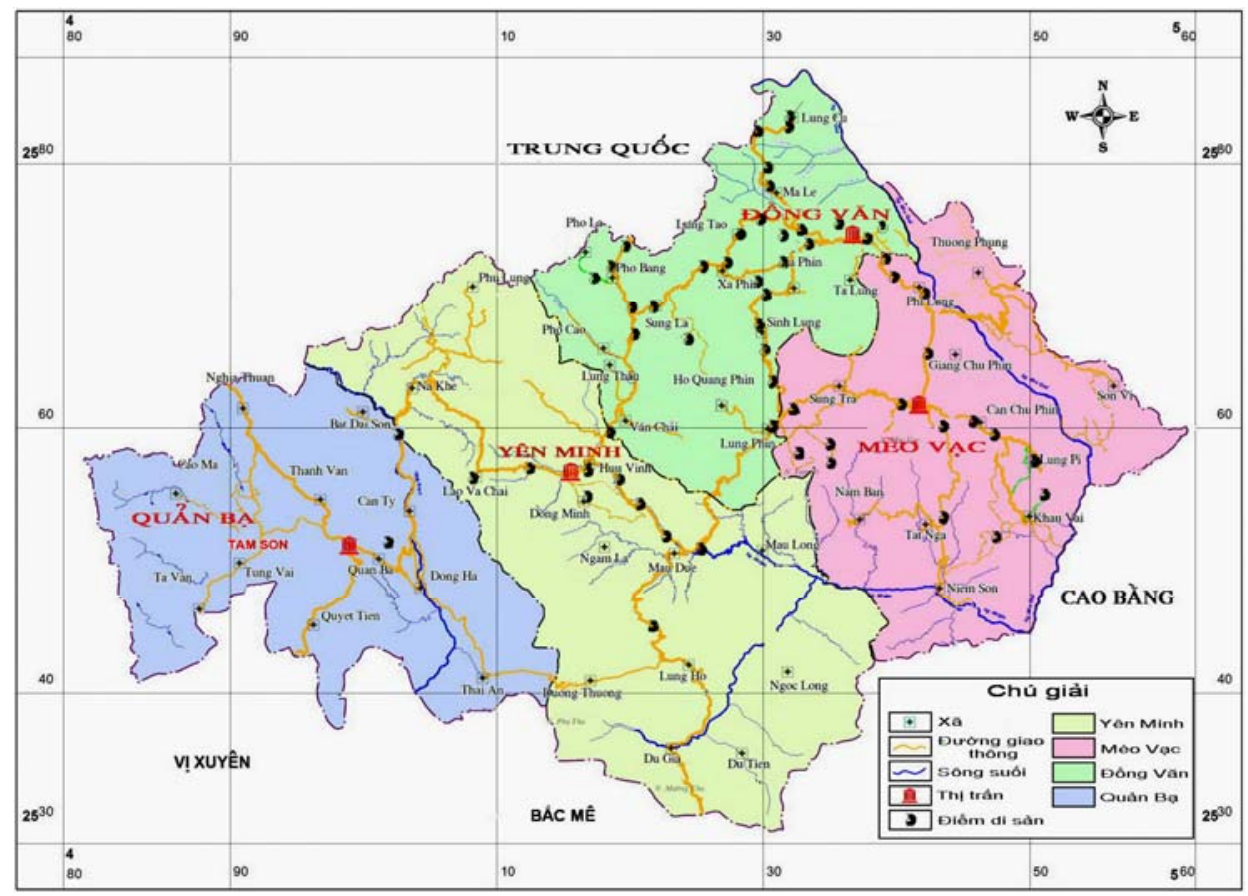

Hình 1. Bản đồ phân bố di sản địa chất ở Cao nguyên đá Đồng Văn 


\section{Di sản địa chất (DSĐC)}

Trên cao nguyên đá Đồng Văn có mặt 19 loại đá khác nhau, gồm: magma, biến chất và trầm tích; được xếp vào 3 giới và 7 hệ, tương ứng với các đại và kỷ. Riêng đá carbonat có tới 10 loại khác nhau với tuổi thành tạo từ 513 triệu năm (hệ Cambri, thống trung - thượng) đến 260 triệu năm (hệ Trias, thống hạ), thuộc nhiều giai đoạn phát triển địa chất và môi trường trầm tích khác nhau, với tổng chiều dày lên tới hơn $3000 \mathrm{~m}$. Tại khu vực này, các nhà địa chất đã xác lập được 139 điểm DSĐC thuộc các kiểu DSĐC chủ yếu sau:

\subsection{Kiểu A: Cổ sinh}

Các nhà cổ sinh đã xác định được (hóa thạch) trên 1000 loài thuộc 120 giống trong đó có 25 loài thuộc 23 giống được phát hiện lần đầu tiên ở $\mathrm{CaO}$ nguyên đá Đồng Văn, như Bọ Ba Thùy ở Lũng Cú, Tay Cuộn ở Ma Lé, Cá cổ và Hai mảnh vỏ ở Xín Mần Kha (Đồng Văn), Trùng Thoi ở phố cổ Đồng Văn; San hô, Huệ biển ở Lũng Pù (Mèo Vạc)... . Các nhóm hóa thạch kể trên sống ở nhiều điều kiện cổ môi trường khác nhau như: lục địa ven bờ (Cá cổ, Thực vật thủy sinh, Ostracoda, Gastropoda), biển nông (Trilobita, Brachiopoda, Bivalvia, Anthozoa, Fusulinida (Foraminifera), Crinoidea), tướng biển sâu (Tentaculita, Conodonta, một số loài của nhóm Bivalvia, Ammonoidea).

- Hóa thạch Cá cố tuổi Devon sớm (hình 2) được tìm thấy ở mặt cắt Lũng Cú - Ma Lé (J. Deprat, 1915) và trên taluy đường ô tô Đồng Văn Lũng Cú (Janvier và Tạ Hòa Phương, 1995) trong phiến sét, bột kết hệ tầng $\mathrm{Si} \mathrm{Ka}\left(\mathrm{D}_{1} s k\right)$.

- Hóa thạch Hai mảnh vó có tuổi Devon (hình 3) hệ tầng Bắc Bun, Mia Lé quan sát được ở mặt cắt Lũng Cú - Ma Lé.



Hình 2. Hóa thạch Cá cổ ở Lũng Cú, Đồng Văn (Nguồn: Tạ Hòa Phương)

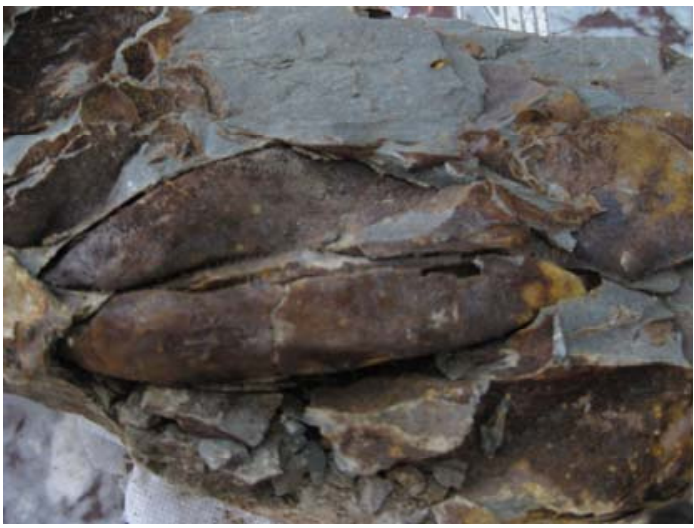

Hình 3. Hoá thạch Hai mảnh vỏ tuổi Devon ở Xín Mần Kha (Nguồn: Lương Thị Tuất)

- Hóa thạch Tay cuộn Devon được tìm thấy ở bản Ma Lé, trên đường ô tô Đồng Văn - Lũng Cú, thuộc mặt cắt Lũng Cú - Ma Lé của hệ tầng Mia Lé (hình 4). Tại đây rất phong phú hóa thạch Tay cuộn, Hai mảnh vỏ và Cá cổ, thậm chí còn được coi như "Nghĩa địa" của hóa thạch Tay cuộn. Tại điểm lộ trên, hóa thạch bảo tồn tốt và rất dễ quan sát, cho phép xác định môi trường thành tạo các trầm tích chứa chúng là biển nông gần bờ.

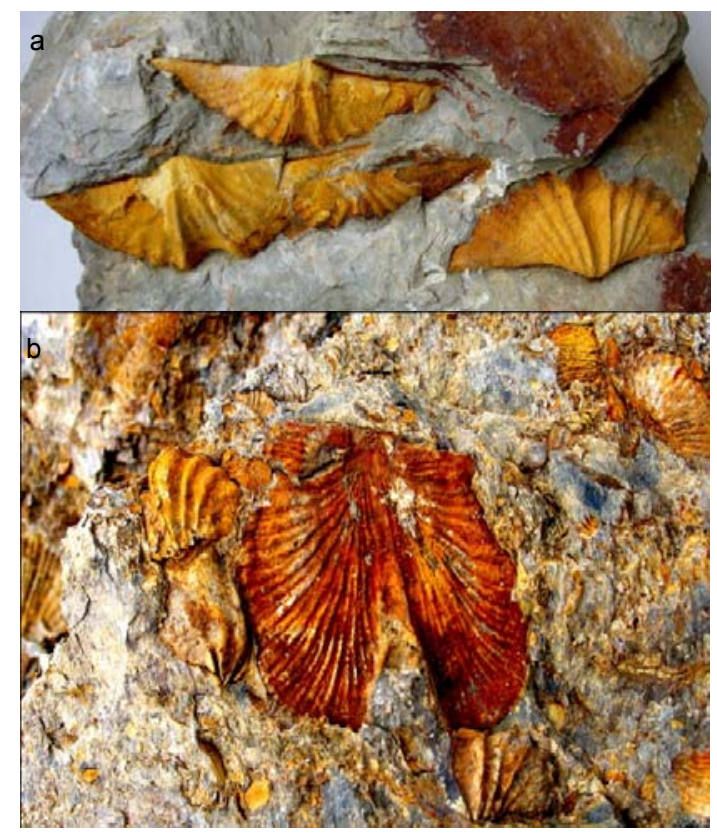

Hình 4. Điểm hóa thạch Tay cuộn Ma Lé với các hóa thạch:

a. Eurispirifer tonkinensis (Mansuy) và b. Dicoelostrophia annamitica (Nguồn: Tạ Hòa Phương) [3] 


\subsection{Kiểu B: Địa mạo}

Thuộc kiểu địa mạo ở đây có các cảnh quan địa hình, hẻm vực, hang động,...

- Cảnh quan địa hình: địa hình cuesta do thế nằm đơn nghiêng của nhiều hệ tầng lục nguyên carbonat rất phát triển trên Cao nguyên đá Đồng Văn. Địa hình cuesta đặc sắc nhất có thể bắt gặp ở ngay dưới chân cột cờ Lũng Cú, trên các tập đá lục nguyên - carbonat phân lớp mỏng - trung bình của hệ tầng Chang Pung $\left(€_{3} c p\right)$. Thực chất nơi đây vốn là một nếp lồi lớn bị đứt gãy phá hủy dọc trục phương TB-ĐN. Phần nhân bị phá hủy trở thành thung lũng, là nơi đồng bào Lô Lô sinh sống với các ruộng ngô và "đôi mắt rồng" - hai hồ nước nổi tiếng mang đậm nét tâm linh. Hai cánh của nếp lồi cắm thoải đơn nghiêng $25-30^{\circ}$ về $\mathrm{B}$ và $\mathrm{TN}$, tạo nên các lớp sóng đá chờm lên nhau. Địa hình cuesta được coi là dạng địa hình đặc sắc của Cao nguyên đá Đồng Văn (hình 5, 20). Ngoài ra, có một cảnh quan rất ấn tượng cạnh "cổng trời" ở thị trấn huyện lỵ Quản Bạ là "Núi đôi Cô tiên" mềm mại và duyên dáng, được hình thành từ núi đá vôi chứ không phải từ trầm tích lục nguyên. Những núi đá vôi này bị dập vỡ mạnh, bị rửa trôi và bóc mòn đều, tạo nên các khối núi cân đối đến lạ kỳ (hình 6 ).

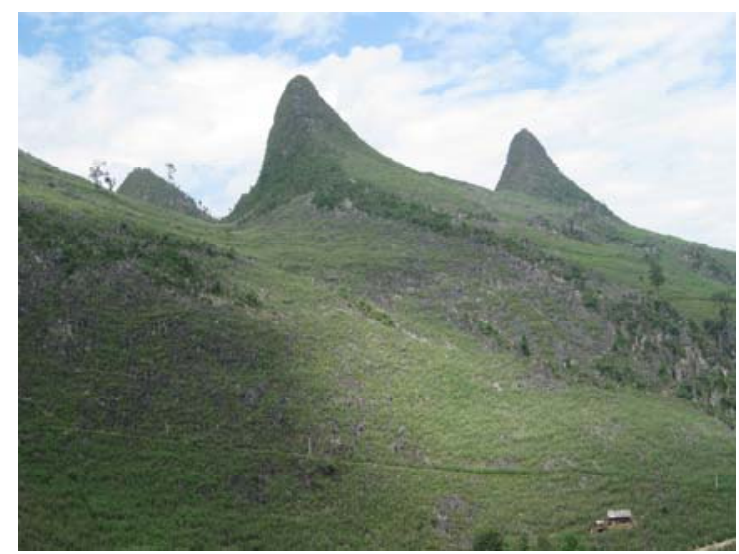

Hình 5. Địa hình cuesta kiểu tháp lệch ở Lũng Hồ, Yên Minh (Nguồn: Lương Thị Tuất)

Đúng ra không chỉ có “đôi gò” này mà là cả một dãy, nhưng đôi gò này đẹp nhất và nằm ở vị trí thuận lợi nhất đối với du khách. Đặc biệt, sự đa dạng về địa hình, cảnh quan karst rất đẹp đẽ và giá trị [1] này lại được xen kẽ một cách hài hòa với các dạng địa hình mềm mại tạo bởi các đá lục nguyên, lục nguyên xen carbonat, như các khối núi, sườn núi có cấu tạo đơn nghiêng, các đồi tròn thoải, các thung lũng sông suối đã tạo nên một cảnh quan tuyệt mỹ cho vùng cao nguyên đá Đồng Văn (Lũng Cú, Phố Bảng, Yên Minh,...).

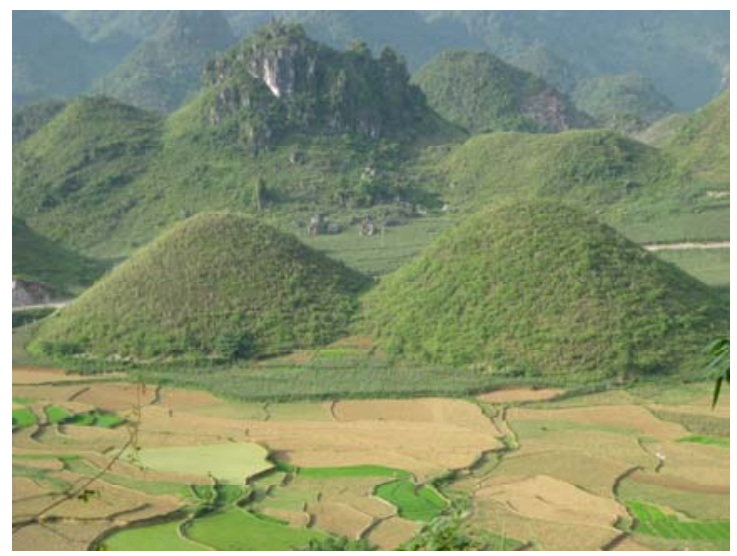

Hình 6. "Núi đôi Cô Tiên" ở Quản Bạ (Nguồn: Lương Thị Tuất) [3]

- Các hẻm vục: hoạt động kiến tạo đã chia cắt cao nguyên đá Đồng Văn thành các khối tảng và chuyển động phân dị mạnh mẽ, tạo sự chênh lệch địa hình lên đến cả ngàn mét, là điều kiện lý tưởng để hình thành nên các hẻm vực, đặc biệt ở các khu vực phân bố đá vôi. Có nhiều hẻm vực karst trên Cao nguyên đá, hẻm vực nào cũng sâu, cũng hùng vĩ nhưng có lẽ hoành tráng nhất trong số đó phải kể đến hẻm vực Tu Sản trên sông Nho Quế (hình 7). Con sông Nho Quế chảy theo hướng TB - ĐN chia cắt cao nguyên, tạo nên thung lũng hình chữ $\mathrm{V}$ điển hình. Trên độ chênh cao tới gần $1000 \mathrm{~m}$ so với lòng sông là quốc lộ $4 \mathrm{C}$ nối hai thị trấn Đồng Văn Mèo Vạc. Trên đó, đèo Mã Pì Lèng là một điểm dừng chân lý tưởng với một bên là núi cao, một bên là vực sâu. Từ đỉnh đèo ngắm nhìn hẻm vực sông Nho Quế sâu hun hút, đặc biệt là đoạn qua bản Tu Sản của người H'Mông, nhìn những đỉnh non cao trùng điệp, những vách đá vôi cao vút, trắng toát của hệ tầng Bắc Sơn. Cũng tại vị trí địa thắng cảnh Mã Pì Lèng này, chúng ta có thể quan sát những nếp uốn kỳ diệu của đá vôi tuổi Devon. Hẻm vực Tu Sản trên sông Nho Quế đoạn đèo Mã Pì Lèng đã trở thành bộ phận trung tâm nổi trội nhất của biểu tượng CVĐC Cao nguyên đá Đồng Văn. Ngoài ra, các dạng địa hình khác như karst dạng nón, dạng chóp (chóp kim Pải Lủng), dạng thành lũy, sườn xâm thực khổng lồ, mảng đá bám, thác nước, "suối đá", ,.. càng làm cho khu vực này trở nên đặc sắc. 


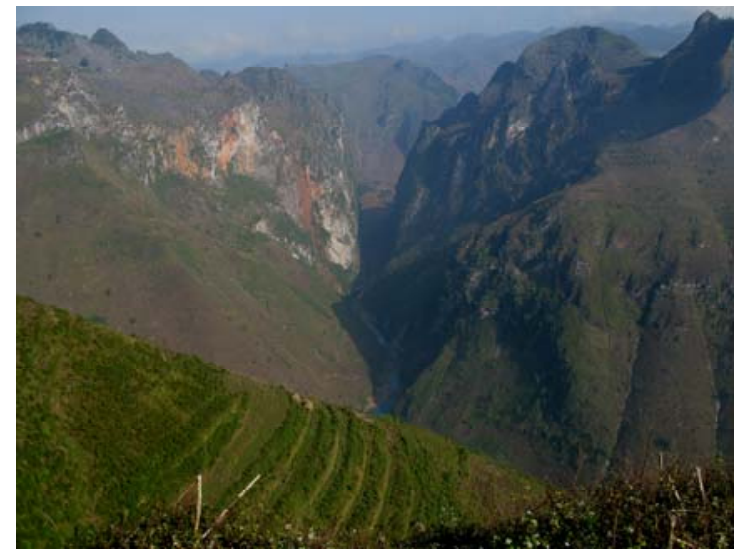

Hình 7. Hẻm vực Tu Sản trên sông Nho Quế (Nguồn: La Thế Phúc, 2010)

- Hang động: hoạt động kiến tạo và môi trường cổ khí hậu đã tạo nên nhiều cảnh quan, nhiều hang động kỳ thú (như: Động Nguyệt, Hang Dơi, Hang Ong (hình 8), Hang Rồng, Hang Mẹ Chúa Ba, Động Én, Xả Lũng, hang Khố Mỷ (hình 9), vừa có giá trị khoa học vừa có tiềm năng phục vụ kinh tế du lịch. Đồng thời, chúng cũng tạo nên nhiều trũng kiến tạo - karst dài 1-8km, sâu 200-700m (các thị trấn Phố Bảng, Đồng Văn, Mèo Vạc; các xã Lũng Phìn, Xà Phìn); nhiều phễu karst quy mô khác nhau (Lũng Chinh, Lũng Cú,...).

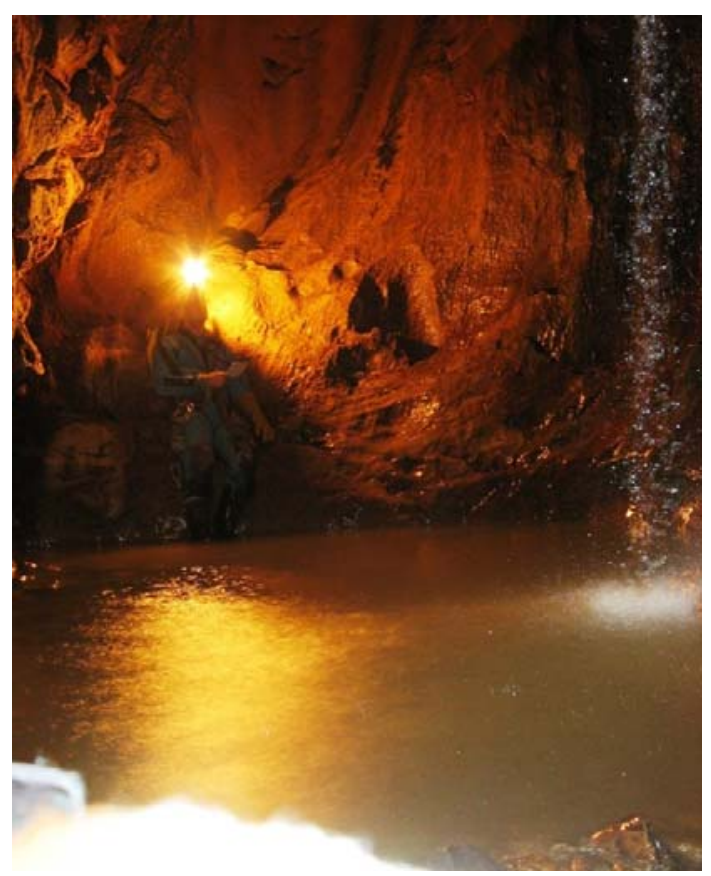

Hìn 8. Hang Ong ở Đồng Văn (Nguồn: VIGMR)

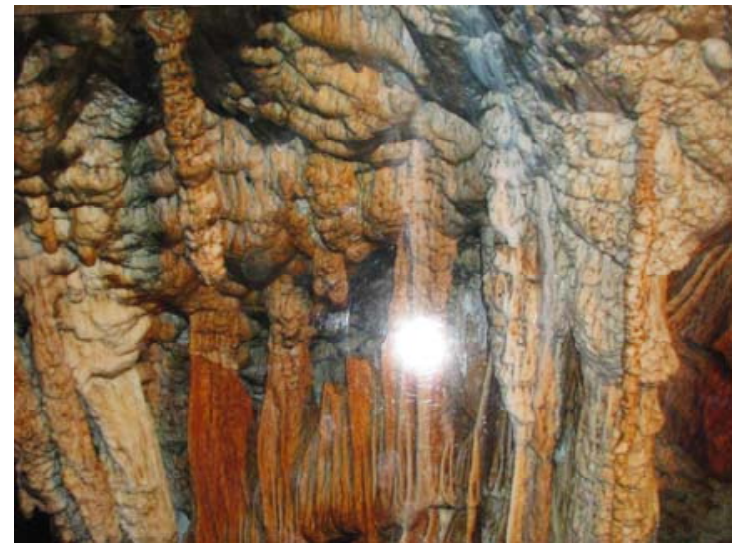

Hình 9. Hang Khố Mỷ ở Quản Bạ (Nguồn: Lương Thị Tuất)

2.3. Kiểu D: Đá (Hỗn hợp: Đá - cổ sinh - cổ môi trường)

Đá vôi Trùng Thoi gặp ở nhiều nơi trên Cao nguyên đá Đồng Văn nhưng vị trí lý thú nhất gặp ở gần mỏ nước sau chợ Đồng Văn. Trùng Thoi (Fusulinid) là một loại động vật đơn bào có vỏ vôi sống trong các đại dương cồ cách ngày nay khoảng 330-251 triệu năm. Khi chết vỏ vôi của Trùng Thoi tích lại tạo nên đá vôi. Nhiều khi vỏ Trùng Thoi nhiều đến nỗi tạo nên đá vôi Trùng Thoi (fusulinid limestone). Đây là bằng chứng chỉ rõ đá vôi ở thị trấn Đồng Văn nói riêng và Cao nguyên đá nói chung được tạo ra trong các đại dương cổ, là bằng chứng về tuồi Permi (cách ngày nay khoảng 270260 triệu năm) (hình 10).

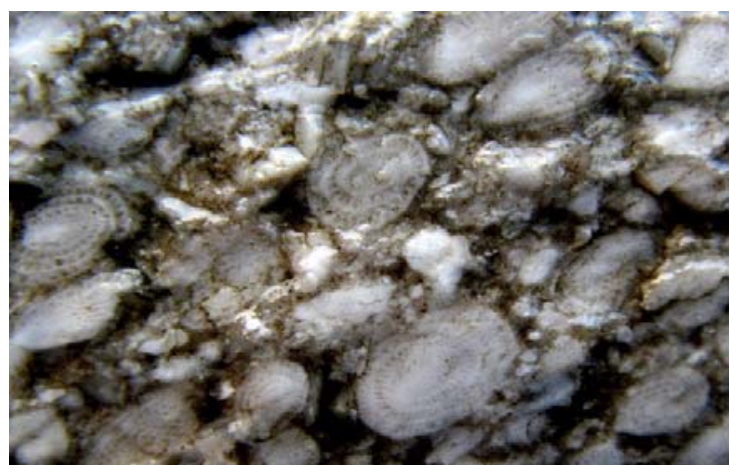

Hình 10. Đá vôi Trùng Thoi ở Đồng Văn (Nguồn: Đoàn Nhật Trưởng)

\subsection{Kiểu E: Địa tầng}

- Ranh giới thời địa tầng giữa 2 bậc Frasni/Famen thuộc Devon thượng đánh dấu sự mở đầu của một trong năm sự kiện hủy diệt hàng loạt thế giới sinh vật, một đột biến lớn trong sự phát triển của sinh giới, với sự biến mất hàng loạt của 
các nhóm hoá thạch lớn như Tay cuộn, San hô, Hai Mảnh Vỏ, Lỗ tầng v.v. Mặt cắt và địa điểm chuẩn quốc tế của ranh giới $\mathrm{F} / \mathrm{F}$ được chọn tại mỏ đá Coumiac Thượng, vùng ĐN Montagne Noire (Pháp). Đó cũng là ranh giới giữa hai sinh đới Răng nón (Conodonta): Palmatolepis linguiformis (trên cùng của Frasni) và $P a$. triangularis (dưới cùng của Famen). Việc nghiên cứu ranh giới thời địa tầng nói chung và ranh giới $\mathrm{F} / \mathrm{F}$ nói riêng rất công phu, tốn kém, và rất ít trường hợp thành công do yêu cầu nghiêm ngặt mà nó đòi hỏi. Ranh giới $\mathrm{F} / \mathrm{F}$ tại mặt cắt Đồng Văn - Nho Quế, đoạn qua đèo Si Phai, một trong hai mặt cắt chứa ranh giới $\mathrm{F} / \mathrm{F}$ được phát hiện ở Việt Nam, đã được xác định với đầy đủ các đới Răng nón theo quy định, rất có ý nghĩa tham khảo và đối sánh quốc tế (hình 11) [3, 4].

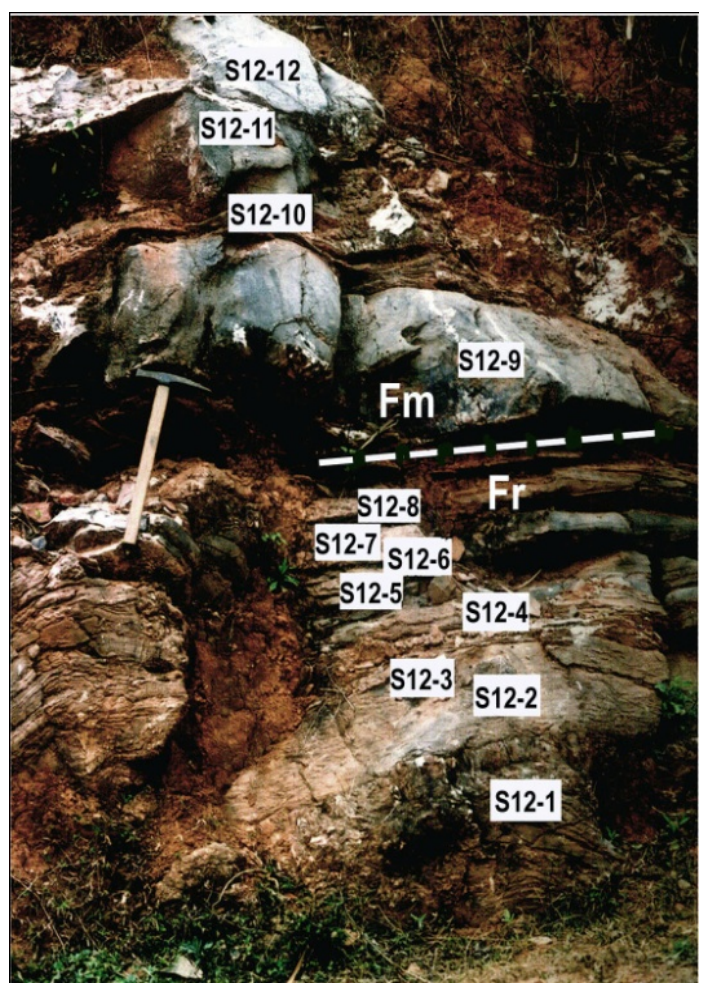

Hình 11. Ranh giới thời địa tầng Frasni/Famen tại đèo Si Phai (Nguồn: Tạ Hòa Phương)

- Ranh giới Permi/Trias $(\mathrm{P} / \mathrm{T})$ là một trong các ranh giới thời địa tầng chính yếu vì đây không những là ranh giới giữa hai đại Paleozoi và Mesozoi mà còn vì tại đây đã xảy ra biến cố cỡ hành tinh làm tuyệt diệt khoảng 90-95\% số giống, loài trong môi trường biển. Việc nghiên cứu ranh giới $\mathrm{P} / \mathrm{T}$ đòi hỏi phải có mặt cắt chuẩn trầm tích liên tục trong khi giữa các trầm tích Permi và Trias trên thế giới lại có một gián đoạn quan trọng. Ở cao nguyên đá Đồng Văn, ranh giới $\mathrm{P} / \mathrm{T}$ được tìm thấy trong những mặt cắt giữa hai hệ tầng Đồng Đăng $\left(\mathrm{P}_{3}\right.$ dđ) và Hồng Ngài $\left(\mathrm{T}_{1} h n\right)$ ở Lũng Pù, Hồng Ngài và Lũng Cẩm. Mặt cắt Lũng Cẩm lộ ra ven đường dân sinh nối với quốc lộ $4 \mathrm{C}$, cách thị trấn Phố Bảng khoảng $4 \mathrm{~km}$ về phía đông - nam (hinh 12).

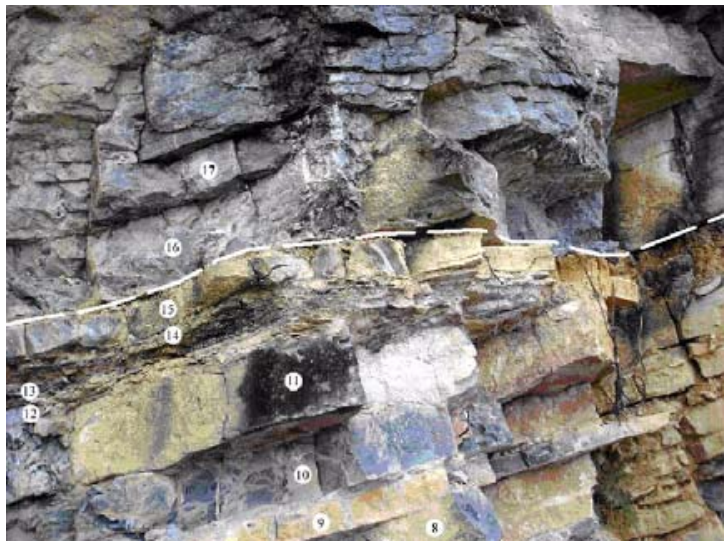

Hìn 12. Ranh giới Permi-Trias nằm giữa lớp 15 và 16 ở Sủng Là (Nguồn: Đoàn Nhật Trưởng)

\subsection{Kiểu I: Kiến tạo (lịch sử địa chất)}

Mặt trượt đứt gãy và đới dăm kết vôi ở Quản Bạ: Đứt gãy Quản Bạ - Hương Chà có phương Tây Bắc - Đông Nam, cắt qua các thành tạo carbonat tuổi Devon, tạo nên đới phá hủy dăm kết ở khu vực Thị trấn Tam Sơn. Mặt trượt đứt gãy ở Quản Bạ trùng phương với đứt gãy, có mặt dốc đứng, cắt qua đới dăm vôi tuổi Devon sớm. Mặt trượt trơn mịn, màu đỏ do chứa oxyt sắt là dấu tích pha hoạt động cuối cùng của đứt gãy này trong giai đoạn Tân kiến tạo (cách khoảng 5 triệu năm - Hiện đại) còn lại đến ngày nay (hình 13). Ngoài ra còn những nếp uốn còn được bảo tồn tốt trong các đá trầm tích lục nguyên, carbonat (ở Mã Pì Lèng)... là minh chứng cho hoạt động kiến tạo phức tạp trong khu vực.

\section{3. Đa dạng sinh học}

Hiện tại, liên quan đến cao nguyên đá Đồng Văn có hai khu bảo tồn thiên nhiên (KBTTN). Một là KBTTN Du Già ở rìa phía ĐN Cao nguyên đá Đồng Văn, nằm giữa ba huyện Yên Minh, Bắc Mê và $\mathrm{Vị} \mathrm{Xuyên} \mathrm{được} \mathrm{thành} \mathrm{lập} \mathrm{theo} \mathrm{Quyết} \mathrm{định} \mathrm{của}$ UBND tỉnh Hà Giang. Hai là KBTTN khác mới được thành lập ở xã Bát Đại Sơn, huyện Quản Bạ theo Quyết định của Cục Kiểm lâm, Bộ Nông nghiệp và Phát triển Nông thôn. 


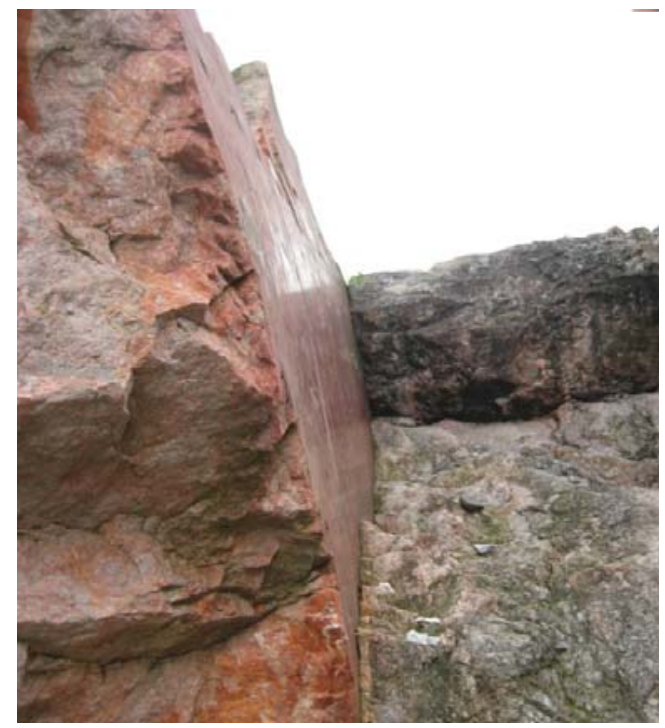

Hình 13. Mặt trượt đứt gãy cắt qua đới dăm kết vôi ở khu vực thị trấn huyện lỵ Quản Bạ

(Nguồn: Lương Thị Tuất) [5]

\section{1. Đa dạng thục vật}

Hà Giang là một trong một số ít vùng của nước ta có tính đa dạng thực vật cao nhất, đồng thời giàu các taxôn đặc hữu và gần đặc hữu nhất. Do các đặc điểm địa lý tự nhiên độc đáo nên các quần thể động thực vật ở khu vực này rất phong phú, đa dạng. Về thực vật, Hà Giang có rất nhiều khu rừng nguyên sinh với nhiều gỗ quý và có tới 1.000 loại cây dược liệu quý hiếm. Nhiều loại thực vật quý hiếm đã được phát hiện trong thời gian gần đây trên phạm vi Cao nguyên đá Đồng Văn, như dẻ tùng sọc nâu, thông tre lá ngắn, hoàng đàn rủ, thông đỏ, cây đỉnh tùng (đã được đưa vào Sách Đỏ Việt Nam, xếp ở cấp R-hiếm gặp-hình 14), cây bảy lá một hoa

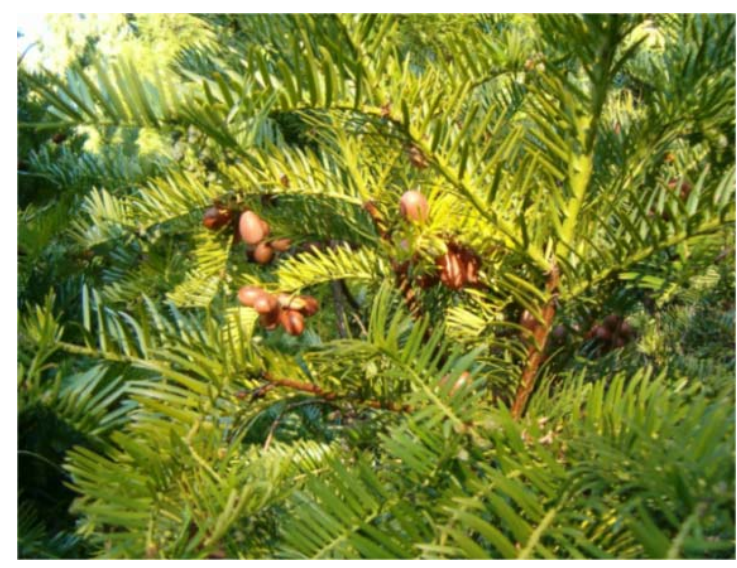

Hình 14. Cây đỉnh tùng (Cephalotaxus hainanensis) (Nguồn: GEF/SGP-UNDP) (cũng được đưa vào Sách Đỏ Việt Nam, xếp ở cấp $\mathrm{R}$ - hình 15), cây bách vàng (Xanthocyparis vietnamensis) được xếp vào hạng cực kỳ nguy cấp (IUCN, 2004), cây Trân châu lá dải,...

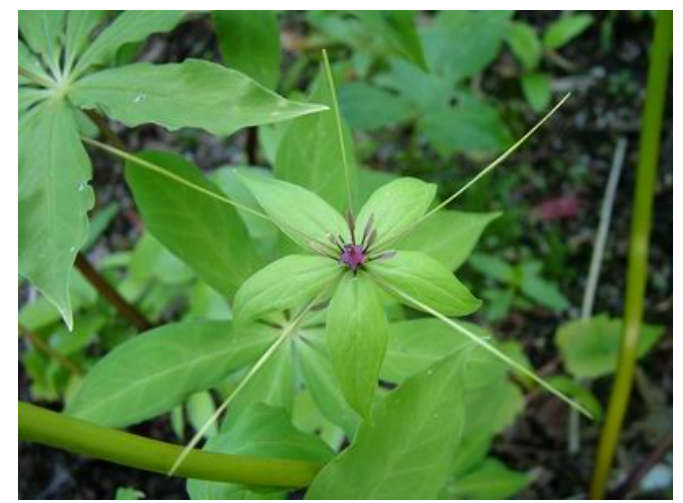

Hình 15. Cây bảy lá một hoa (Paris polyphilla) ở CVĐC Cao nguyên đá Đồng Văn (Nguồn: christiealpines.co.uk)

\section{2. Đa dạng động vật}

Ở Hà Giang và đặc biệt là trên Cao nguyên đá Đồng Văn, đa dạng động vật nuôi và động vật hoang dã có những đặc điểm rất khác biệt so với những khu vực khác trong cả nước. Các quần thể này là nguồn lưu trữ vật liệu di truyền tiềm năng có lợi ích kinh tế và di sản vì chúng thích ứng tốt với các điều kiện khó khăn, có sức đề kháng cao với bệnh tật và khả năng sinh sản cao.

Đáng chú ý nhất là việc phát hiện ra loài voọc mũi hếch (Tonkin snub-nosed monkey (TSN), (Rhinopithecus avunculus) (hình 16), một loài voọc

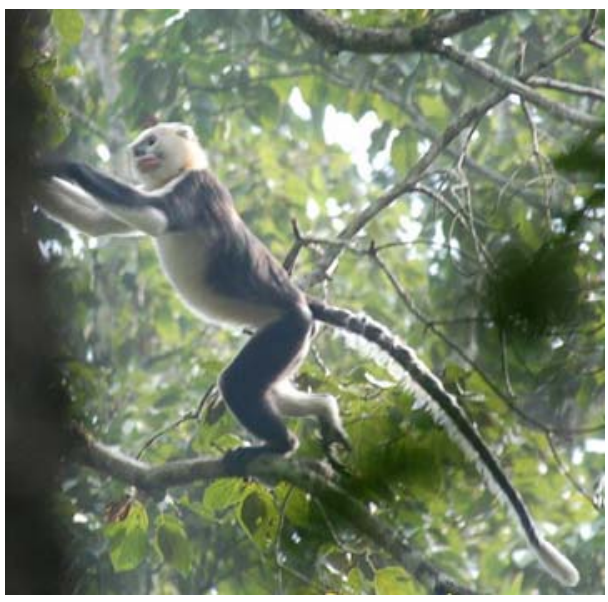

Hình 16. Voọc mũi hếch ở KBTTN Du Già (Nguồn: Lê Khắc Quyết) 
đặc hữu của miền Bắc Việt Nam ở KBTTN Du Già và vùng đệm rừng $\mathrm{Khau} C \mathrm{Ca}$ trên $\mathrm{Cao}$ nguyên đá Đồng Văn. Chúng được liệt vào danh sách 25 loài linh trưởng nguy cấp nhất thế giới. Một số đợt khảo sát mới đây đã phát hiện thêm một đàn voọc mũi hếch nữa cách xã Tùng Vài, huyện Quản Bạ khoảng $40 \mathrm{~km}$ về phía Bắc, sát biên giới Trung Quốc. Hiện nay voọc mũi hếch ở Cao nguyên đá Đồng Văn đang được một số dự án quốc tế cùng chính quyền và người dân địa phương giám sát chặt chẽ với một loạt hoạt động tuyên truyền, giáo dục nâng cao nhận thức cộng đồng. Chúng thực sự là một di sản quý giá của Cao nguyên đá Đồng Văn.

\section{4. Đa dạng lịch sử văn hoá xã hội}

Kết quả khai quật khảo cổ đã khẳng định Hà Giang là một vùng đất cổ có những di chỉ đánh dấu những giai đoạn chính trong quá trình phát triển lịch sữ đất nước. Đó là những di tích Thời đại Đá cũ Đồi Thông, Bó Khiếu; di tích Sơ kỳ Thời đại Đá mới Đán Cúm, Nà Chảo; di tích Hậu kỳ Đá mới sau Hòa Bình hang Nà Bếp; di tích Hậu kỳ Đá mới - Sơ kỳ kim khí Lò Gạch v.v. Nhiều hang động vừa là di tích văn hoá, vừa là địa điểm khảo cổ như các hang Bó Khiếu, Đán Cúm, Nà Chảo ở Bắc Mê; hang Thẩm Ké ở Quản Bạ; hang Phố Bảng ở Đồng Văn,.. Trống đồng của đồng bào Lô Lô ở Đồng Văn là di vật tiêu biểu cho thời kỳ dựng nước, là nét thống nhất trong đa dạng của nền văn hóa - văn minh Đông Sơn của người Việt cổ phát triển trên đất Hà Giang.

Cao nguyên đá Đồng văn có hai khu di tích lịch sử đã được xếp hạng Quốc gia là: Di tích kiến trúc nghệ thuật Dinh thự họ Vương (xã Xà Phìn, huyện Đồng Văn, xếp hạng quốc gia năm 1993) (hình 17), Cột cờ Lũng Cú trên đỉnh núi Rồng (xã Lũng Cú, huyện Đồng Văn, xếp hạng quốc gia năm 2008) (hình 18). Hai khu này nằm trong quần thể các khu Di tích Lịch sử Văn hoá đã được xếp hạng Quốc gia ở Hà Giang, gồm: Di tích lịch sử Căng Bắc Mê (huyện Bắc Mê, được xếp hạng năm 1992); Di tích lưu niệm sự kiện Bác Hồ với Hà Giang (Thị xã Hà Giang, 1993); Di tích Bia và Chuông chùa Sùng Khánh (huyện Vị Xuyên, 1993); Di tích lịch sử cách mạng Tiểu khu Trọng Con (huyện Bắc Quang, 1996); Di tích khảo cổ học hang Đán Cúm (huyện Bắc Mê, 2001); Di tích khảo cổ học hang Nà Chảo (huyện Bắc Mê, 2001); Di tích lịch sử Văn hoá chuông chùa Bình Lâm (huyện Vị Xuyên, 2005); và các DSVH Phố cổ Đồng Văn, Chợ tình Khâu Vai...

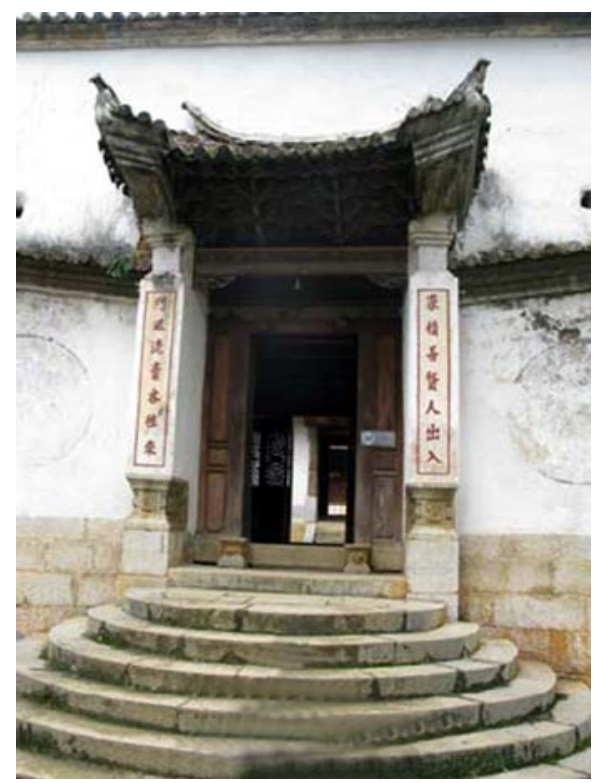

Hình 17. Dinh thự Họ Vương ở xã Sà Phìn, huyện Đồng Văn

(Nguồn: La Thế Phúc, 2010)

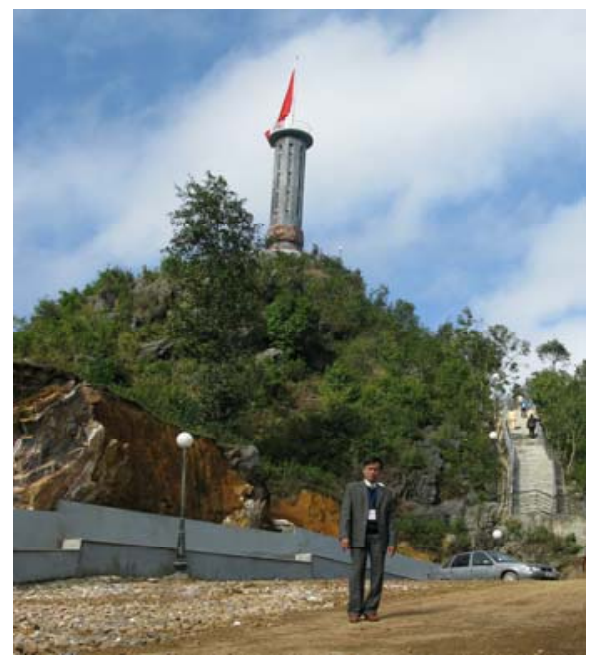

Hình 18. Cột cờ Lũng Cú, Đồng Văn (Nguồn: La Thế Phúc, 2010)

\section{Lễ đón nhận danh hiệu công viên địa chất toàn cầu}

Căn cứ vào quy mô và tính đa dạng về DSDC, sinh học và lịch sử văn hoá xã hội...; các nhà Địa chất của Viện Khoa học Địa chất và Khoáng sản đã phối hợp với UBND tỉnh Hà Giang xây dựng hồ sơ CVĐC và đệ trình UNESCO vào tháng 11-2009. Vào cuối tháng 6 - đầu tháng 7-2010, UNESCO đã 
cử đoàn công tác đến Cao nguyên đá Đồng Văn để khảo sát và thẩm định theo các tiêu chí về CVĐC do UNESCO ban hành. Ngày 03-10-2010, tại Hội nghị CVĐC Châu Âu lần thứ 9 tổ chức ở Lesvos Hi Lạp, UNESCO đã quyết định công nhận CVĐC Cao nguyên đá Đồng Văn là thành viên Mạng lưới CVĐC toàn cầu (GGN) năm 2010-2014. Thành công này là kết quả của sự nỗ lực vượt bậc của các cấp chính quyền địa phương và sự hợp tác nghiên cứu giữa các nhà khoa học Việt Nam và Bỉ trong nhiều năm qua. Ngày 01/12/2010, UBND tỉnh Hà Giang đã tổ chức buổi lễ long trọng để đón nhận danh hiệu cao quí này (hình 19). Như vậy, CVĐC Cao nguyên đá Đồng Văn đã trở thành CVĐC toàn cầu đầu tiên của Việt Nam.

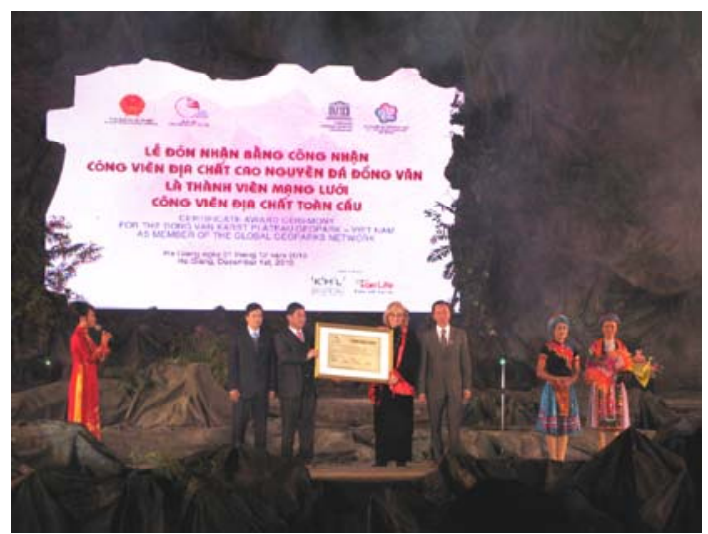

Hình 19. Trao tặng và đón nhận Bằng công nhận Công viên Địa chất Toàn cầu của UNESCO và Lãnh đạo tỉnh Hà Giang (Nguồn: La Thế Phúc, 2010)

\section{Vấn đề bảo tồn di sản địa chất ở cao nguyên đá Đồng Văn}

Hiện nay, các văn bản pháp quy liên quan tới bảo vệ bảo tồn di sản nói chung đã có. Từ các văn bản pháp quy có hiệu lực cao là các Luật (như: Luật Di sản, Luật Khoáng sản, Luật Môi trường,...); văn bản dưới Luật có các Nghị định của Chính phủ hướng dẫn thực hiện Luật; và các Thông tư của các Bộ ngành, liên Bộ ngành; đến các văn bản pháp quy ở mức thấp hơn là các quy định, nội quy, quy chế của chính quyền địa phương (như tỉnh, huyện, xã) và các cơ quan quản lý trực tiếp (là các Ban quản lý ở các khu di sản, vườn quốc gia,...). Nội dung các văn bản này còn chung chung, khái niệm về DSĐC chưa được xác định và làm rõ, chưa có chế tài đủ mạnh để răn đe. Công tác tuyên truyền giáo dục để nâng cao nhận thức cộng đồng về khoa học địa chất, về DSĐC, về bảo vệ môi trường thiên nhiên,... còn yếu kém cả về nội dung lẫn hình thức [2]. Người dân và thậm chí cả các doanh nghiệp, cơ quan chủ quản chưa nhận thức được ý nghĩa to lớn, thiết thực của việc bảo tồn DSĐC; vì vậy luôn có sự xung đột giữa phát triển cơ sở hạ tầng (như: xây dựng nhà cửa dịch vụ, nhà dân sinh, làm đường giao thông), khai thác khoáng sản..., phát triển dịch vụ du lịch với bảo tồn DSĐC; xung đột giữa mức thu nhập kiếm sống hàng ngày của người dân nghèo với bảo vệ bảo tồn DSĐC... Thực tế DSĐC và môi trường sinh thái ở đây đang bị xâm hại do các hoạt động khai thác khoáng sản như: khai thác quặng antimon ở Mậu Duệ (Yên Minh) (hình 20, 21); khai thác đá xây dựng,

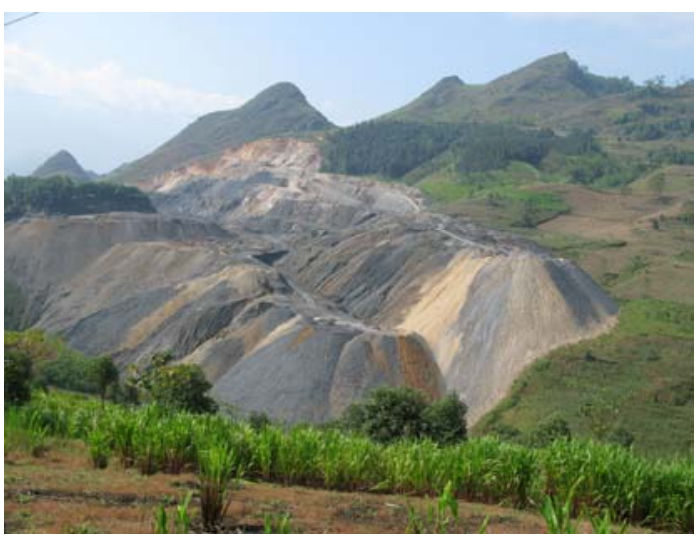

Hình 20. Khai thác quặng antimon ở Mậu Duệ đã xâm hại di sản địa mạo và môi trường sinh thái của CVĐC Đồng Văn (Nguồn: La Thế Phúc, 2010)



Hình 21. Dòng suối hiếm hoi ở khu vực Mậu Duệ, thuộc Cao nguyên đá Đồng Văn dường như đã "chết" do khai thác antimon (Nguồn: La Thế Phúc, 2010) 
đá vôi, đá cảnh... Do vậy, cần phải có chiến lược bảo tồn di sản nhằm giải quyết tốt các mối "xung đột" nêu trên để bảo tồn DSĐC, bảo vệ môi trường và giữ vững danh hiệu $\mathrm{CV} Đ C$ toàn cầu đã được UNESCO trao tặng.

Nhìn ra thế giới, chúng ta sẽ thấy công tác bảo tồn DSĐC ở các nước phát triển được thực hiện rất tốt mà chúng ta cần phải học tập. Thí dụ: Đảo Jeju ở Hàn Quốc được UNESCO công nhận là DSTN Thế giới vào năm 2007. Đây là một hòn đảo có rất nhiều miệng núi lửa tạo cảnh quan đẹp, rất nhiều hang núi lửa ngoạn mục được bảo vệ bảo tồn một cách rất nghiêm ngặt. Trước khi được nghiên cứu xác lập các giá trị DSĐC và xây dựng hồ sơ trình duyệt UNESCO; tại các vùng "lõi” của DSĐC có dân cư sinh sống, có các đường giao thông đi qua, có khách sạn, nhà hàng, có các công trình công cộng, các trạm thu phát tín hiệu viễn thông truyền hình,... Sau khi được UNESCO công nhận là DSTN Thế giới, ngay lập tức, chính quyền tỉnh Jeju đã chi hàng trăm triệu USD để thực hiện công tác bảo vệ bảo tồn, đầu tư xây dựng và nâng cấp cơ sở hạ tầng trong vùng phân bố DSĐC. Nhiều con đường giao thông đã được di dời ra khỏi vùng lõi. Dân cư sinh sống trong vùng lõi được tài trợ để di chuyển ra vùng đệm. Các khách sạn, nhà hàng cũng được di rời ra vùng đệm. Các trạm thu phát tín hiệu viễn thông, truyền hình, trạm quan trắc khí tượng thuỷ văn,... trong vùng lõi (nằm trên các DSĐC) đều được di chuyển đi nơi khác để trả lại nguyên trạng cho di sản. Đối với những hang động núi lửa độc đáo, có giá trị khoa học - thẩm mỹ cao, người ta thành lập Bảo tàng địa chất ngoài trời, xây dựng cổng bảo vệ rất kiên cố (có chuông báo động) để bảo vệ bảo tồn di sản và thu phí vào cửa. Trên bề mặt của nền hang được xây dựng những con đường bằng thép rất chắc chắn để phục vụ du khách. Người ta đã nghiên cứu lắp đặt hệ thống đèn chiếu sáng trong các hang động, trang trí hài hòa với cảnh quan xung quanh nhằm tôn tạo vẻ đẹp tự nhiên của hang. Việc lắp đặt hệ thống đèn chiếu sáng ở từng vị trí cũng được tính toán kĩ lưỡng để đảm bảo tiêu chuẩn thích hợp về bước sóng, tránh các tương tác làm xâm hại di sản và gây ô nhiễm môi trường (You Bong Kim, 2007) (hình 22-25).


(Nguồn: You Bong Kim, 2007)

\section{Kết luận và kiến nghị}

Qua kết quả nghiên cứu về DSĐC và nhân sự kiện UNESCO công nhận Cao nguyên đá Đồng Văn là thành viên mạng lưới Công viên Địa chất toàn cầu, tập thể tác giả có một vài kết luận và kiến nghị sau:

- Cho đến nay, công tác nghiên cứu DSĐC theo hướng bảo tồn và khai thác hợp lý được các nhà địa chất Việt Nam thực hiện khá tốt, cách tiếp cận vấn đề và giải quyết vấn đề phù hợp với thế giới, đạt được những kết quả thiết thực rất đáng khích lệ, đáp ứng yêu cầu phát triển bền vững và hội nhập Quốc tế;

- Tiềm năng tài nguyên DSĐC ở Cao nguyên đá Đồng Văn là to lớn, rất đa dạng và phong phú nhưng chưa được nghiên cứu chi tiết và đầy đủ; cần tiếp tục đầu tư mở rộng nghiên cứu bảo tồn, quản lý và khai thác bền vững $\mathrm{DS} Đ C$; nhân rộng mô hình CVĐC ở Việt Nam; 
- Để xây dựng thành công công viên Địa chất cần phải có sự kết hợp chặt chẽ giữa các nhà khoa học với chính quyền địa phương, sự năng động cần thiết của các địa phương;

- Các cấp thẩm quyền nên có những giải pháp tối ưu để giải quyết mối "xung đột" giữa hoạt động khai thác, chế biến khoáng sản với bảo tồn DSĐC và bảo vệ môi trường sinh thái;

Công trình được hoàn thành dưới sự hỗ trợ của đề tài khoa học công nghệ cấp Nhà nước mã số KC.08.20/06-10.

\section{TÀI LIẸU DÃNN}

[1] Lê Đức An, Đặng Văn Bào, 2008: Cao nguyên Đồng Văn - Mèo Vạc: một di sản địa mạo karst quý giá. Tạp chí các Khoa học về Trái Đất, T.30, 4DC; 534-544. Hà Nội.

[2] La Thế Phúc, Trần Tân Văn, 2009: Nghiên cứu di sản địa chất và xây dựng công viên Địa chất ở Việt Nam. Tạp chí Địa chất; 310; 10-19. Hà Nội.

[3] Tạ Hoà Phuơng, Đặng Văn Bào, Nguyễn Văn Vuợng, Vũ Cao Minh, Phạm Văn Lục, 2008: Một số giá trị địa chất - cảnh quan vùng cao nguyên đá Đồng Văn - Mèo Vạc đáp ứng xây dựng công viên địa cảnh (Geopark). Tạp chí các Khoa học về Trái Đất, T.30, 2, 105-112. - Hà Nội.

[4] Tạ Hoà Phuoong, Nguyễn Thị Thuỷ, Đoàn Nhật Trưởng, Nguyễn Công Thuận, 2004: Về ranh giới Frasni/Famen (Devon thượng) ở Đông Bắc Bắc Bộ. Tạp chí các Khoa học về Trái Đất, T.26, 3, 216-221. Hà Nội.

[5] Luoong Thị Tuất, Trần Tân Văn, Đoàn Thế Anh, Hồ Tiến Chung, Phạm Việt Hà, Đặng Trần Huyên, Đàm Ngọc, Đố Thị Yến Ngọc, Nguyễn Đại Trung, Phạm Khả Tuỳ, Đoàn Nhật Truởng, 2010: Kiến thức bản địa về di sản địa chất ở công viên địa chất cao nguyên đá Đồng Văn, tỉnh Hà Giang: một vài khám phá bước đầu. Tạp chí Địa chất; 317-318; 149-162. Hà Nội.

\section{SUMMARY}

\section{Dong Van rock highland - the first international Geopark of Vietnam and geoheritage preservation}

Dong Van Karst Plateau has the richness and diversity in geoheritages. Initial research conducted by Vietnamese and foreign geologists highlighted five types of geological heritages (according to UNESCO classification): type Apalaeogeology, type B- geomorphology, type D- rock, type E-stratigraphy, type I-tectonics. Besides geoheritages, the biodiversity and the historical, cultural and societal richness of Dong Van Karst Plateau (which met UNESCO criteria of a global geopark), has made it recognised as a member of global Geopark Network by UNESCO for the years 2010 2014. The management, conservation and rational exploitation of heritages (especially geoheritages) should be raised seriously and given priority in every economic development strategy of the local government, in order to maitain its honourable title and enhance the sustainable socio-economic development.

This paper introduce some main features of Dong Van Karst Plateau Geopark, the event of the UNESCO rewarding Dong Van Karst Plateau with the title "Global Geopark" and the issues of preservation of its local geoheritages. 